\title{
What's Special about the State?
}

\author{
HELENA DE BRES
}

Wellesley College

\begin{abstract}
Many of us think that we have duties of distributive justice towards our fellow citizens that we do not have towards foreigners. Is that thought justified? This article considers the nature of the state's relationship to distributive justice from the perspective of utilitarianism, a theory that is barely represented in contemporary philosophical debates on this question. My strategy is to mount a utilitarian case for state-specific duties of distributive justice that is similar in its basic structure to the one that is standardly mounted for special duties towards the near and dear. I begin with a discussion of whether or not the co-citizen relationship can be justified in terms of its welfare consequences. I then consider what the answer to that first question implies concerning the duties of distributive justice that arise within that relationship.
\end{abstract}

What, if anything, is special about the state, where distributive justice is concerned? Or, to put the question somewhat more precisely, is there something about the state that makes duties of distributive justice either exclusive to it or significantly different in nature within it and, if so, what is that something? The interest of this question derives from a clash between two intuitions. On the one hand, many of us feel that matters of distributive justice have a particular significance within the context of domestic politics. On the other hand, when we reflect on what we mean by distributive justice in the abstract, this thought seems difficult to sustain. By general agreement, distributive justice involves the following four features. First, it is concerned with the distribution of socio-economic goods, broadly construed. The general class includes such material items as income and wealth, medicine, food, housing and clothing, along with more immaterial items such as rights, powers, duties, liabilities, employment, leisure and education. Second and third, distributive justice has a diachronic and systematic focus, in the sense that it applies most readily to ongoing practices of production and distribution, rather than to one-off allocations of a fixed pool of goods. And fourth, the obligations deriving from distributive justice are collective in nature: they fall in the first instance on groups of people, and are only then translated into individual duties. Note that, while these features together make the state a plausible site of distributive justice, they do not obviously single it out as a privileged such site, especially in contemporary circumstances of globalization. Yet the first intuition lingers. So the question is: what, if anything, might justify that thought? 
Attempts to answer this question abound in the recent philosophical literature on global justice. ${ }^{1}$ In this article, I want to consider the nature of the state's relationship to distributive justice from the perspective of a theory that is barely represented in those current debates. That theory is utilitarianism, according to which, in a slogan, all moral requirements are based on a single fundamental duty to maximize the sum-total of well-being. ${ }^{2}$ Much of what I say here will extend to versions of welfare consequentialism other than utilitarianism, but utilitarianism represents the hardest, and in that respect the most interesting, case. Vindicating the intuition that the state is somehow special in regard to distributive justice is not an easy task for any theory. But the prospects of a utilitarian coming even close to vindicating it might seem truly dim, for the following reason. In the case of many theories, the idea that we have state-specific duties of distributive justice is taken to be relatively unproblematic, and the key task is conceived as that of determining whether or not we have other duties of distributive justice also, and, if so, how these might differ from the intra-state kind. But in the case of utilitarianism, there exists an apparently serious problem with establishing even the first of the claims just mentioned. The idea that co-citizens might have duties of distributive justice towards each other that they do not have towards the rest of the world seems prima facie dubious from a utilitarian perspective. Duties of domestic distributive justice in effect require citizens of well-off countries to prioritize, through the institutions of their state, the resource-related interests of their co-citizens over the resource-related interests of the billions of people outside their state who are extremely deprived. Given that we can assume that the marginal utility of resources is much higher at the bottom than the top of the well-being distribution, this arrangement looks highly inefficient from a utilitarian standpoint. Put in more humane terms, it looks like an unconscionable discounting of the urgent needs of the global poor.

1 To take just one journal, see e.g.: Thomas Nagel, 'The Problem of Global Justice', Philosophy and Public Affairs 33 (2005), pp. 113-47; Joshua Cohen and Charles Sabel, 'Extra Rempublicam Nulla Justitia?', Philosophy and Public Affairs 34 (2006), pp. 14775; A. J. Julius, 'Nagel's Atlas', Philosophy and Public Affairs 34 (2006), pp. 176-92; Arash Abizadeh, 'Cooperation, Pervasive Impact and Coercion: On the Site (not Scope) of Distributive Justice', Philosophy and Public Affairs 35 (2007), pp. 318-58; Andrea Sangiovanni, 'Global Justice, Reciprocity, and the State', Philosophy \& Public Affairs 35 (2007), pp. 2-39.

2 More precisely, in the classical act-utilitarian form: an act (or policy, institution, motive, decision-procedure, etc.) is morally right if and only if the total amount of wellbeing for all minus the total amount of ill-being for all that is produced by that act (etc.) over the long run is equal to or greater than this net amount for any other available act (etc.). 
My aim here is to consider the question of whether or not utilitarians can, despite the unpromising appearances just mentioned, endorse the idea that we have state-specific duties of distributive justice and then to draw out the implications of that inquiry for the broader question with which I began: that of what is special, or what isn't, about the state in relation to distributive justice more generally. It should be fairly obvious why utilitarians should care about this subject. But I think there are at least two reasons why non-utilitarians should do also. One reason is captured in Mill's claim in On Liberty that 'both teachers and learners go to sleep at their post, as soon as there is no enemy in the field'. ${ }^{3}$ Utilitarianism's supposed inability to provide a compelling case for special duties to co-citizens is often thought to be one of several problems rendering it an unpromising contender for an acceptable account of global justice. If a better case for such duties can be mounted, utilitarianism will to that extent emerge as a more robust opponent and this can be expected to improve the quality of argument on the other side of the field also. A second reason to care about what I am about to say has an Hegelian rather than a Millian flavor. Whatever our philosophical sympathies, all of us are to some degree concerned with the consequences of actions and institutions for human welfare and we all have reason to worry about the way in which the concentration of redistributive policies within state borders measures up in that respect. If it can be shown that at least some degree of current co-citizen partiality can in fact be justified in welfarist terms, that fact might provide the psychological benefit of going partway towards 'reconciling us to our social world'.

\section{THE TRADITIONAL STRATEGY}

The problem of justifying state-specific duties of distributive justice is one instance of a more general, and familiar, problem for utilitarians. This is that of justifying special duties, understood as 'duties that we have only to those particular people with whom we have had certain significant sorts of interactions or to whom we stand in certain significant sorts of relations'. ${ }^{5}$ In general, such duties require one to prioritize, in various ways and to various degrees, the interests of those with whom one is associated over the interests of others. There is a long history of utilitarian defenses of partiality of this kind in the case of friends and family. The traditional argument has two steps. First, we are told that a world containing fulfilling friendships and close family

\footnotetext{
3 James Stuart Mill, On Liberty (London, 1921 [1859]), p. 25.

4 See John Rawls, The Law of Peoples (Cambridge, 1999), pp. 124-8.

5 Samuel Scheffler, Boundaries and Allegiances (Oxford, 2001), p. 49.
} 
relationships is more conducive to welfare than one without. Then we are told that the goods of friendship and kinship are impossible without certain kinds of favoritism. It is part of being a good friend, for instance, that you devote a disproportionate amount of your time and resources to your friend and part of being a good wife that you pull your drowning husband out of the lake before pulling out some equally floundering stranger. The conclusion is that if we want to attain the welfare-maximizing goods of friendship and kinship, we need to allow for the forms of favoritism that are their precondition. ${ }^{6}$

While this is a familiar utilitarian move in the case of special duties to friends and family, however, a fully elaborated comparable move in the case of special duties of distributive justice between cocitizens is hard to come by. Why? Perhaps it is because the argument seems from the outset much harder to do successfully in the latter case. Distributive justice, by its nature, typically applies not to oneoff, small-scale instances of resource allocation, but rather to entire schemes of production and distribution. The way in which the rules governing such schemes are set determines, in an ongoing fashion, the basic distribution of socio-economic resources on the basis of which individuals make their own personal allocation decisions. Endorsing special duties of distributive justice therefore involves sanctioning partiality at a deep level and on a significant scale. This would seem to require a much more heroic feat of justification than the friendship and kinship cases, which involve partiality, at the level of individual duties, to a small circle of people.

Other doubts about the possibility of mounting a successful utilitarian justification for state-specific duties of distributive justice are of a more general nature and apply equally (in a suitably tailored fashion) to the friendship and kinship cases. Co-citizenship is a form of association that occurs as a direct result of the division of the world into a system of states. The question of whether or not the co-citizen relationship can be justified, then, reduces to the question of whether or not the modern state system can be. Two concerns immediately arise in relation to this second question. The first is epistemic: how could we ever know whether the modern state system is welfare-maximizing?

6 This is a move within the more general strategy known as 'indirect' utilitarianism. The idea is that, owing to the various difficulties that arise in applying the principle of utility directly in the context of everyday decision-making (lack of information, limited calculative ability, practical incapacity, coordination problems, 'expectation effects', and so on), utilitarians need to identify a distinct set of 'secondary' principles or duties, tailored to specific sorts of manageable decision problems, the general acceptance of which will maximize aggregate well-being over the long term. Special duties will be among these secondary duties, the positing of which conduces to the maximal overall good. 
The type and amount of information we would need to settle the issue appear out of our reach. ${ }^{7}$ The second concern is practical. The modern state system is by now so well entrenched that the prospects of eliminating, replacing or altering it in any significant way seem vanishingly slim. This suggests that, even if, contra the epistemic concern, our question could be answered, that answer promises to be practically inert. Perhaps the only sensible thing for utilitarians to do, in response to these concerns, is to abandon the traditional strategy in this case, and opt out of assessing the general welfare consequences of the co-citizenship relation. Instead they would take the state system, in its essentials, as given: a background to their theorizing rather than an object of it.

While this might well turn out to be the only viable option, it should nonetheless come at the cost of considerable discomfort to a utilitarian. This is because, when an institution has immense implications for human well-being, as the institution of the state certainly does, there is a real danger that ignoring the moral case for or against its existence will massively skew one's conclusions about what it is morally appropriate to aim for, within and around that institution, even at the margin. Is there a way to defend the traditional strategy here and avoid this discomfort? Note that the practical concern about mounting a justification of the modern state system mentioned above assumes two things. First, it assumes that if the state system were shown to be unjustified, the only appropriate response would be largescale and fundamental change (now outside the bounds of practical possibility). Second, it assumes that the large-scale and fundamental response in question would be institutional, not moral, in nature. We would restructure the state system itself, rather than restructure (our understanding of) the duties that are habitually conjoined to it. Neither of these assumptions need be accepted. As I will suggest below, existing problems within the state system might call for reform rather than revolution. And should even institutional reform prove infeasible, a further alternative would be to argue for either fundamental or incremental change in our attitudes concerning the moral significance of citizenship. ${ }^{8}$ The epistemic concern about the futility of attempting

\footnotetext{
7 Part, but only part, of the difficulty here is that of identifying all of the relevant alternatives. As Sidgwick puts it, 'when we abandon the firm ground of actual society we have an illimitable cloudland surrounding us on all sides, in which we may construct any variety of pattern states' (Henry Sidgwick, Methods of Ethics (Indianapolis, 1981 [1907]), p. 22).

8 Of course, these too might turn out to be resistant. See Sidgwick, Methods, p. 473: ‘The utilitarian, in the existing state of our knowledge, cannot possibly construct a morality de novo either for man as he is (abstracting his morality) or for man as he ought to be and will be. He must start, speaking broadly, with the existing social order ...' Still, the
} 
to justify the state system can also be lessened in two ways. First, the worry at issue raises the bar too high. Consequentialist justifications will always be hostage to elusive facts and therefore to doubts. But many such arguments can nonetheless be quite convincing up to a point. This may not be one of those cases, but, given our practical interest in the matter, there is something to be said for making a genuine attempt. Second, as I will suggest below, we can make that attempt while accommodating a key part of the epistemic concern, by letting facts about what we can and can't know figure into the justification that we give.

Here, then, I want to attempt the more ambitious traditional strategy, and try to mount a case for state-specific duties of distributive justice similar in its basic structure to that standardly mounted for special duties towards the near and dear. I begin, in the next section of the article, with a discussion of whether or not the form of relationship under consideration - here, the state system - can be justified in terms of its welfare consequences. I then consider, in the following section, what the answer to that first question implies concerning the duties here of distributive justice in particular - that might arise within that system.

\section{HOW TO LEARN TO LOVE THE STATE SYSTEM}

The first step of what I have called the traditional utilitarian strategy for establishing special duties is to establish the welfare-maximizing nature of the relationship within which the duties in question are said to hold. The only piece of existing utilitarian writing that touches on this question in any detail in the case of the modern state system is a 1988 paper by Robert Goodin. Goodin points out that, as a general matter, the best way to ensure that the interests of a group of people are protected or promoted is often to divide that group into smaller subgroups, each of which is assigned its own special agent or protector. ${ }^{9}$ This strategy works by reducing standard strategic constraints on welfare promotion - such as problems of information, collective action, and limits on altruistic motivation - that would otherwise be pressing. ${ }^{10}$ Goodin suggests that we view the state system as one instance of

claim that there is no room for movement in our moral attitudes in this area requires a strong argument.

9 Robert Goodin, 'What Is So Special About Our Fellow Countrymen?', Ethics 98 (1988), pp. $663-86$ (681).

10 This type of argument finds one of its classic statements in William Paley's Principles of Moral and Political Philosophy (New York, 1824 [1786]), p. 201: 'The good order and happiness of the world are better upholden whilst each man applies himself to his own concerns and the care of his own family . . . than if every man, from an excess of mistaken generosity, should leave his own business, to undertake his neighbour's, 
this general type of case. From a utilitarian perspective, we can think of that system as an 'administrative device' for the promotion of global welfare. ${ }^{11}$ Given that we generally have better information about, greater capacity to affect, and stronger motivation to assist those nearest to us than those living far away, dividing the world up into separate political communities is a much more effective means of promoting aggregate global welfare than is a global philanthropic free-for-all. The various redistributive programs and social insurance schemes operative within modern states provide a concrete example of this mechanism at work. Evidently, not all states have such schemes, and, equally evidently, those schemes that do exist are imperfect in many respects. But most of us - including many of those who are on balance critical of these programs - agree that, in the states where they have been instituted, public education, medical care, transportation, pensions, food stamps and unemployment benefits have constituted a major improvement in the ability of citizens to attain a basic level of welfare. Even more of us would agree that these programs (difficult enough to maintain in modern societies) would not have been at all feasible to implement on a global scale. ${ }^{12}$

We can call the above line of thought the 'global division of moral labor argument'. This argument will certainly provide a very significant component of any utilitarian justification for the state system. But it will only provide part of that justification, for two reasons. The first is that it fails to capture some of the specific reasons why the existence of a plurality of distinct, relatively self-contained political communities is beneficial. It is not just that the basic welfare goods provided by a system of relatively autonomous political communities of the kind that Goodin describes would be less efficiently secured in the absence of such a system. It is also, I want to suggest, that there exist some welfare-related goods that can only be provided in that way. ${ }^{13}$

which he must always manage with less knowledge, conveniency, and success.' See also Sidgwick, Methods, pp. 433-4.

11 Goodin, 'What Is So Special', p. 685.

12 Scholars worry about the ability of the national welfare state to survive under conditions of globalization and multiculturalism: see e.g. the papers collected in Pranab Bardham, Samuel Bowles, and Michael Wallerstein, Globalization and Egalitarian Redistribution (Princeton, 2006). However, it is rare to suggest that the solution to the problem is to create a global welfare state.

${ }_{13}$ Goodin's failure to acknowledge this is unfortunate. When he writes that ' $[\mathrm{t}$ ] boundaries are merely useful devices for "matching" one person to one protector. Citizenship is merely a device for fixing special responsibility in some agent for discharging our general duties vis-à-vis each particular person' ('What Is So Special', p. 686, my italics), he gives a deflationary impression of the moral significance of states. This needlessly rubs people up the wrong way. See Kok-Chor Tan, Justice Without Borders: Cosmopolitanism, Nationalism and Patriotism (Cambridge, 2004), p. 148: 'Just as it would be crass to reduce the worth of the relationship of friendship to the 
I think we can point to four such goods in particular. The first is democracy. It is highly plausible that the exercise of genuine democratic agency is possible only within a world containing a plurality of distinct political communities. Considerations purely of scale suggest that whatever forms of governance we develop at the fully global level will not be able to provide for either the kind of transparency and oversight or for the sense of genuine political participation and connection to one's representatives that democracy within smaller populations affords. ${ }^{14}$ A second good arguably obtainable only within a global order involving distinct, relatively self-contained, communities is that of significant cultural diversity. We can think of such communities on the model of isolated ecological niches, providing a protected environment for the development of distinctive life forms that might not otherwise have survived. Cultural diversity is a 'system-level' consequence of the organization of the globe into relatively selfcontained political communities, rather than a good internal to those communities themselves. A similar, third, type of good can be identified in the scope for large-scale institutional experimentation that such a form of organization affords. Just as the states in a federal system of government provide a useful way of simultaneously testing the merits of alternative institutional structures and policy measures, the existence of a variety of distinct political communities results in a much richer understanding of the scope of institutional possibility and of the merits of specific social, economic, and political options than would be available in a unitary system. Finally, we can point to the good of political community or social solidarity. It is again highly plausible that a robust sense of communal identification and sympathetic concern is possible only amongst groups of people smaller than the global population as a whole.

merely instrumental one of promoting the greater good, likewise it would be a serious misdescription of the moral worth of citizenship if we think it is merely an administrative device for discharging our general duties to humanity.'

${ }_{14}$ Some have claimed that democracy would in fact be much better realized in the world if it were to be instituted at the fully global level. This suggestion draws on the 'principle of affected interests', according to which democracy requires that all those affected by a decision ought to have a say in making it. (For the principle, see Robert Dahl, Democracy and its Critics (New Haven, 1989).) This principle is certainly violated in our world, by virtue of the fact that the decisions of individual states on such matters as environmental, health and trade policy now, more than ever, have consequences that extend far beyond the borders of those states themselves. Pogge argues that this fact 'requires democratic centralization of political decision-making' at the international level (Thomas Pogge, World Poverty and Human Rights (Cambridge, 2002), p. 187). In response, I should emphasize that my argument is not intended to rule out supplementing democracy at the level of subglobal political communities with something in some respects like democracy at the regional or global level. Instead I am claiming that political communities smaller than the entire global population are necessary, although perhaps not sufficient, for achieving the full measure of democratic agency. 
In considering why utilitarians in particular should care about the goods just mentioned, we can distinguish two broad types of answer. One, indirect, route points to the way in which the goods in question promote distinct goods that are themselves of a welfaremaximizing nature. The good of democracy can be partly defended in this way, by reference to its epistemic value in selecting among a set of distinct options. Utilitarians have often argued that decisions made democratically are more likely over time to lead to the choice of welfaremaximizing policies than are decisions imposed by a small minority, because individuals are, at least as a general rule, both better judges and better guardians of their own interests than are other people. ${ }^{15}$ The good of institutional experimentation on the global plane can be defended in a similarly epistemic way, by reference to its informational virtues. However, it can also, along with the good of cultural diversity, be defended by appeal to the value of personal autonomy. The availability on the global plane of a diversity of ways of life enriches the set of options accessible to individuals generally, thereby increasing the scope of individual freedom. Depending on their theory of welfare, utilitarians might think of autonomy, in turn, as an irreducible constituent of a person's well-being or, again, as a core means by which a person determines wherein her well-being consists.

A second general type of argument points to the way in which the good in question is valued intrinsically by individuals, in such a way that its obtaining directly contributes to their welfare. Thus a distinct utilitarian justification for democracy points to the fact that, for at least very many people, the ability to cooperate with other members of one's political community in determining the shape and future direction of that community is valuable in itself, as an important aspect of a fully dignified life. Similarly, the good of membership in (or 'belonging' to) a political community is something that very many people value directly, independently of the socio-economic benefits that such membership often brings.

I suggest that the above considerations help to capture more fully than the global division of moral labor argument taken alone why

${ }^{15}$ For the classic statement, see Mill's On Liberty. Political scientists have also argued for a connection between democracy and economic prosperity. Olson argues that prosperity depends on secure property and contract rights, the latter of which depend on the very same conditions - a reliable court system, independent judiciary and respect for law, and individual rights - that underlie a lasting democracy (Mancur Olson, 'Dictatorship, Democracy and Development', American Political Science Review 87 (1993), pp. 567-76). Przeworski makes the different argument that prosperity requires effective state intervention in the market and that the latter requires democratic accountability (Adam Przeworski, 'A Better Democracy, A Better Economy', Boston Review (April/May 1996)). Since the connection between economic prosperity and welfare is indirect, these arguments are, even if successful, at best suggestive. 
it is that a utilitarian might endorse a global institutional set-up involving a plurality of discrete populations, each governed by its own unique set of political institutions. In fact, taken together with Goodin's argument, which remains a central component of the case, I believe that they provide the foundations for a very strong utilitarian justification for that general type of arrangement. However - and this is the second respect in which Goodin's argument remains incomplete for our purposes - they fail by themselves to get us all of the way to a justification of the modern state system in particular. To see this, note that although the modern system does incorporate a plurality of distinct populations, it also exhibits a number of additional features. Most saliently, it includes a set of governments that: (i) have eminent domain over disjoint, fixed and mutually exclusive parcels of territory, (ii) enjoy an internal monopoly of coercive force, and (iii) are ultimately subject to no higher authority when conducting their internal and external relations. None of these features are inevitable in a global institutional structure involving plural populations. ${ }^{16}$ Examples of alternative structures that lack them include a global (or set of regional) confederation(s); the system of rule employed in medieval Europe, which 'was structured by a non-exclusive form of territoriality, in which authority was both personalized and parcelized within and across territorial formations'; ${ }^{17}$ and Thomas Pogge's 'verticallydispersed sovereignty' model: a 'multi-layered global order'18 in which persons would 'be citizens of, and govern themselves through, a number of political units of various sizes, without any one political unit being dominant and thus occupying the traditional role of state'. ${ }^{19}$

The problem that this poses for the case that I have given so far, if that case is conceived as an argument for the state system in particular, should be clear. Because each of the above (and other) alternative global institutional arrangements incorporates some degree of autonomy for its subunits, the arguments that I have given in favor of a plural system do not select the modern state system over any of them. And yet more problematically, some of these alternatives are argued to do better than the state system on a number of other criteria with which utilitarians

16 The modern conception of territoriality, in particular, is such a familiar and central feature of global political organization that it might be difficult to imagine alternatives to it. But, as Ruggie points out, systems of rule need not be territorial at all (they could be, and have been, kin-based instead), territorial systems need not be territorially fixed (as evidenced by nomadic societies), and the concept of territoriality need not entail mutual exclusion (persons might instead be permitted to move freely across borders). See John Gerard Ruggie, 'Territoriality and Beyond: Problematizing Modernity in International Relations', International Organization 47 (1993), pp. 139-74.

17 Ruggie, 'Territoriality and Beyond', p. 150.

18 Pogge, World Poverty and Human Rights, p. 183.

19 Pogge, World Poverty and Human Rights, p. 178. 
ought to be concerned. The most frequent and serious charges against the current system concern matters of international security, domestic justice and global public goods. The state system is said to encourage war in two ways: the insularity of states fosters aggressive forms of nationalism, leading to inter-state struggles for power, wealth and territory, and the norm of state sovereignty impedes any international attempts to draw unruly states into line. ${ }^{20}$ The second of these features is also said to leave intra-state injustices, such as violations of human rights and failures of domestic distributive justice, without effective remedy and to impede the development of the forms of global cooperation and regulation that are necessary to solve contemporary problems involving the environment, public health, poverty, and the stable and effective management of the international economy.

To what extent do such concerns undermine a utilitarian case for the modern state system? The criticisms that I've mentioned are often taken to call for a complete overhaul of that system: the utter disappearance of the state. I am yet to be persuaded, for two reasons. The first is that it is far from clear to me that the above concerns cannot be addressed by something falling far short of global revolution, namely: reform of some current norms associated with the state system and the supplementation of state governance with further transnational regulation. As examples of the kinds of reform that might be required, we might, say: amend the exclusive right of states to benefit from the natural resources found within their territories, by taxing domestic resource use for the benefit of the global poor; ${ }^{21}$ condition the current unlimited power of states to exclude foreigners from their territories, by liberalizing international immigration law in some respects; ${ }^{22}$ and strengthen recent moves toward a norm of universal jurisdiction, according to which any state is entitled to prosecute certain crimes in its national courts without regard to where the crime was committed or to the nationality of the perpetrators or victims. ${ }^{23}$ A utilitarian case can plausibly be mounted for developments

${ }^{20}$ Security considerations of this kind are sometimes used to argue for a 'world state' possessed of a global monopoly of coercive power, on the reasoning that in an anarchical world - especially one containing weapons of mass destruction - political communities need a Hobbesian 'power to keep them all in awe'. Not only do the considerations given earlier in favor of a plurality of distinct political communities seriously undermine the case for a world state, but it is unclear how it would even serve peace. Such a massive concentration of power would plausibly invite tyranny by its wielders and violent competition for its control.

21 Thomas Pogge, 'Eradicating Systemic Poverty: Brief for a Global Resources Dividend', in Pogge, World Poverty and Human Rights, pp. 196-215.

${ }_{22}^{2}$ Lant Pritchett, Let Their People Come: Breaking the Gridlock on Global Labor Mobility (Washington D.C., 2006).

${ }^{23}$ Stephen Macedo, Universal Jurisdiction: National Courts and the Prosecution of Serious Crimes under International Law (Philadelphia, 2006). 
of this kind, and others like them. But it is not clear that that case would constitute a case against the modern state system. For, a number of significant and distinctive features of the current system would remain even if these and similar changes were made. We would still be left with a fixed and reasonably exclusive form of territoriality, a high degree of centralization of political authority within each individual political unit, the substantial concentration of many of the traditional functions of the state within national borders, and a still commanding role for state governments within the global economy. This, in my view, would count as reform, not revolution.

The second reason why I fail to be persuaded that the continued existence of the modern state system lacks utilitarian justification derives from the following line of thought. If we had come to settle on a system of plural communities that was radically different all the way down to the current one, it might well have served the utilitarian goal just as well or better, on the criteria I discussed earlier, or others. But, as we move down to the more fundamental aspects of the modern state system that I have just mentioned - those that shift the terrain from reform to genuine revolution - the costs of significant change, given that the current system is already in place, are likely to be extremely high. ${ }^{24}$ Now, the utilitarian is famously not averse to cracking some eggs on the way to the omelette. Nonetheless, if a radical alternative to the modern state system were to be justified on utilitarian grounds now, given the likely costs of instituting it, we would have to have at least a very good reason for thinking that the result would be a significant net improvement in human welfare. At present, especially in advance of examining the results of reform, it seems safe to say that we have no idea whether or not this would be the case. This fact recommends a strong presumption, for now, in favor of the broad contours of the status quo arrangement, suitably reformed. ${ }^{25}$ While this line of thought may

${ }^{24}$ Of course, there is also the question, touched upon earlier, of whether or not revolution is even practically possible. If it isn't, and if 'ought' implies 'can', we would have yet another reason to reject the revolutionary argument.

${ }_{25}$ The argument that I give here is similar in form to that offered in Mathias Risse, 'What to Say about the State', Social Theory and Practice 32 (2006), pp. 671-98, and Aaron James, 'Equality in a Realistic Utopia', Social Theory and Practice 32 (2006), pp. 699-724. Risse writes: 'In the light of what we are ever likely to know, in our current and expected historical position, any radical move away from the state system will not be justified given likely costs to collective, national self-determination - one of the state system's main advantages. For whatever the potential advantages for peace, security, legitimacy, and democracy, we are likely to be too uncertain about whether such gains really do require revolution as opposed to mere reform.' James accepts the basic form of argument, but argues that Risse's version is weakened by its reliance on the controversial value of national self-determination. Instead, James advocates replacing that value with the much more widely endorsed value of effective poverty reduction (p. 707). My version of the argument substitutes the value of poverty reduction with the broader value of 
sound conservative, it is only minimally so. It appeals to the status quo only as a means of deciding between a subset of options that resist clear ranking on other grounds and, as I have emphasized, it is intended to leave room for the desirability of significant reforms. The suggestion is only the modest one that the basic system of dividing the world's population into territorially based communities organized under a state is - now - an essential part of the best strategy for maximizing global welfare. If that is so, utilitarians ought to consider the existence of that system morally acceptable. ${ }^{26}$

It might be wondered whether this appeal to the status quo constitutes an abandonment of what I have been calling the first step of the traditional utilitarian strategy for establishing special duties. In effect, am I not back-tracking and admitting that the epistemic and practical concerns about attempts to provide a consequentialist justification for the state system that I canvassed in section II are defeating? So let me clarify. We can distinguish between two kinds of pragmatism in political theorizing. One kind doesn't ask the question of how basic political, social, and economic arrangements might be justified at all, on the grounds that, if ethical theory is to be both possible and action-guiding, it will need to assume from the outset some fundamental facts concerning present-day reality. ${ }^{27}$ Another kind of pragmatism does ask the justificatory question, but allows facts about limits on our practical capacity and knowledge to feed into the justification provided. I earlier rejected the first kind of pragmatism (at least for present purposes) ${ }^{28}$ but have just endorsed the second.

\section{THE STATE AND DISTRIBUTIVE JUSTICE}

The set of arguments that I have given above provides utilitarians with a case for the state system that, although incomplete, looks like it has a good chance of succeeding. This means that the first step in the

welfare, which (given plausible assumptions) will include both poverty reduction and collective self-determination amongst its key components.

${ }_{26}$ An advantage of this argument from the status quo is that it helps to diminish the suspicion that any utilitarian defense of the modern state system must be implausibly Panglossian. It would, after all, be a little surprising if we had just happened to settle in 1648 upon the very best of all of the many global institutional options available at that time.

27 See Rawls, Law of Peoples, pp. 11-12.

28 The first kind of pragmatism might well be appropriate for other purposes. See Richard Brandt, Morality, Utilitarianism and Rights (Cambridge, 1992), p. 351: 'It looks as if morality has to operate on two levels, on one level being free to criticize and attack the institution of private property (marriage, etc.) - this is the level proper for reformers and on another level being required to accept this institution as a going concern and to support principles regulating behavior on the assumption the institution is there - the morality for everyday life.' 
traditional argument for special duties (i.e. a utilitarian justification for the existence of the relationship at issue) appears to have a reasonable foothold in the case of co-citizen relationships. If the second step of the traditional argument is also to go through, we need to consider what role special duties - in particular, given our purposes here, special duties of distributive justice - might play in sustaining those relationships.

The first point to note is that, if the utilitarian argument for the state system that I have given here is correct, there is very good reason for utilitarians to reject the idea - mentioned earlier as a prima facie implication of their view - that we should always weigh the interests of compatriots and foreigners exactly alike when evaluating the distributive consequences of our society's basic institutions. The immediate result of such a policy would be the dissolution of what I earlier called the 'global division of moral labor' between political communities: we would be back (at best) at the global philanthropic free-for-all on which the state system was meant to be an improvement. If utilitarians consider the state system to be morally justified, and in particular if they do so in large part because of the global division of moral labor that that system establishes, they should also consider justified the kind of co-citizen distributive favoritism that is a precondition of that global division.

This result should come as no great surprise, since the point of the global division of moral labor argument, after all, is not simply that drawing borders around people is welfare-maximizing, but that according people within those borders a special responsibility to further each others' interests in various ways is. But the further arguments that I have added to Goodin's 'administrative efficiency' story provide us with two additional ways to argue for special duties of domestic distributive justice under utilitarianism that are both less immediately self-evident and that imply more substantive conclusions than the bare idea that some degree of favoring is necessary.

The first draws on a similar general form of argument to that we have just seen, although it appeals to considerations of democracy and political community rather than administrative efficiency. I argued earlier that part of the utilitarian justification for the state system depends on the way in which that system provides for the exercise of democratic agency and a sense of membership or civic solidarity amongst co-citizens. But note that these goods come with certain distributive preconditions. In particular, as many political theorists have argued, democracy and civic solidarity plausibly require both the guarantee of a certain 'social minimum' of resources below which citizens are not permitted to fall and the elimination of excessive inequalities in wealth across the population. Material deprivation and 
substantial domestic inegalitarianism establish status distinctions and barriers to understanding that undermine social inclusion. They also undermine democracy, both by undercutting the political liberty of the disadvantaged and by reducing the motivation of the citizen body as a whole to vote on the basis of the common good rather than their own partisan concerns. Utilitarians need to formulate principles of distributive justice to address these problems. And, importantly for our purposes, these principles will necessarily be state-specific: because the valuable forms of socio-political relationship that they are intended to promote are themselves contained entirely within the borders of individual states. So, again, if utilitarians consider the state system to be morally justified, and in particular if they do so in part because of the way in which that system secures democracy and a sense of political community, they should also consider justified the special duties to co-citizens that are the preconditions of those goods.

The arguments that I have given so far for positing special duties of distributive justice towards co-citizens draw directly on the substance of the utilitarian justification for the state system that I gave in the previous section of the article. Another potential reason for recognizing such special duties draws on that justification in a more indirect way. It begins with the following thought. Once a state is up and running, a special set of associative conditions is activated. Citizens are engaged, through the basic institutions of their state, in an ongoing form of regular, intentional, collective behavior, sustained by general adherence to a system of rules and norms. Those rules and norms have determinate and consequential effects on citizens' interests, and they are alterable: they might be arranged in other ways and if they were so arranged their results would be different. When these conditions - regularity, intentionality, normativity, significance and alterability - apply to a given social structure, a distinctive kind of moral question arises about that structure: that of whether or not it is distributively fair to those who participate in it. This question is importantly different from the question (just discussed) of whether or not the structure at issue promotes goods such as democracy or a sense of political community. While the latter question has an explicitly consequentialist structure, the fairness question points to concerns of equity, non-discrimination and reciprocity that are, on the face of it, non-consequentialist in nature.

Despite their apparently deontological character, however, these fairness concerns may turn out to be something that utilitarians have reason to take very seriously (as 'secondary principles') within certain associative contexts. This is because distributive fairness within some such contexts may be expected to promote broadly egalitarian distributive outcomes and/or forms of socially beneficial cooperation 
that utilitarians have reason to value. This claim is tentative, because the jury remains out both on the philosophical question of how much egalitarianism is required by fairness and on the largely empirical question of how much welfare is produced by egalitarianism or cooperation. ${ }^{29}$ However, if the domestic basic structure is one context where this argument goes through (and it seems to be one of the more promising candidates), utilitarians will have yet another reason to posit at least some duties of distributive justice that extend exclusively between co-citizens. The restriction to co-citizens derives from the fact that citizens are the only ones participating in, and hence liable to unfair treatment under, the basic structure of their own state.

Now, one could point to the need for such state-specific duties of distributive fairness within utilitarianism without referring to the justification for the state system that I outlined above. Once we have a fairness-apt basic structure in place, a utilitarian might claim, we have a reason to posit these duties regardless of whether or not the state is justified. But there is something unsatisfying about this stand-alone claim. Without a reason to think that the existence of the modern state is morally acceptable, a worry arises that attending to making it fair a task that may impose significant internal distributive requirements is an objectionable distraction from other pressing concerns. Having an independent justification for the state bolsters the utilitarian case for duties of domestic distributive fairness by easing this particular worry. If we have strong moral reasons to have a state system in place, we can follow through on reasons to make domestic political and economic institutions fair with a better utilitarian conscience.

\section{A CHALLENGE}

I think that the response just given is correct as far as it goes, but it does bring to light one important objection to the general line of argument for special duties to co-citizens that I have offered here. As I have presented it, the traditional utilitarian strategy for establishing special duties comes in two independent steps. First we establish the welfare-maximizing nature of the type of relationship at issue. Then we demonstrate how certain sorts of favoritism (in the form of special duties) are preconditions of that relationship (and hence of its value). But, while this procedure has its methodological advantages, there

29 The claim that egalitarian redistribution is in some circumstances welfaremaximizing, owing to the supposed fact of the diminishing marginal utility of resources, has long been a staple of utilitarian political thought and has equally long had its detractors. For a relatively recent example of the latter, see David Schmidtz, 'Diminishing Marginal Utility and Egalitarian Redistribution', Journal of Value Inquiry 34 (2000), pp. 263-72. 
is reason to believe that the two steps that it involves are not as independent as I have been making out. In order for the second step of the traditional strategy to go securely through, special duties have to be shown to have a very tight connection - either intrinsic or causal to the relationship under consideration. (It has to be 'part of being' a friend that you favor your friend in certain ways, or a 'necessary precondition' of democratic citizenship that you prioritize the interests of your co-citizens in certain resource allocations.) But, if the connection really is this tight, when we assess the welfare consequences of the relationship under consideration in the first step of the argument, we need to include the welfare consequences of the special duties attached to that relationship among the consequences that we consider.

The substantive objection to which this methodological point is leading can be put in this way. Once we understand the distributive implications, in terms of special duties, of the utilitarian justification for the modern state system given earlier, does that justification survive? Or, instead, when we see just how much co-citizen favoritism is required to ensure the goods of well-functioning social insurance schemes, democracy, political community, cultural diversity and institutional experimentation, do we discover that those goods are, net, not good enough to give the state system the utilitarian seal of approval? If so, following the traditional strategy (now suitably rectified), special duties to co-citizens will have to be rejected.

This problem appears at its starkest when we consider the way in which special duties between co-citizens aimed at securing democracy and political community can direct resources away from the global poor. We need a strong argument to explain, in utilitarian terms, how these state-based goods (however welfare-enhancing when considered in isolation) could possibly compete with the welfare benefits of a simple redirection of the resources of the affluent toward the world's radically deprived. Part of the difficulty here is that the state-based goods seem much more rarefied in nature than the basic welfare goods of adequate food, shelter and medical care for the world's 'bottom billion'; another part of the difficulty is that only a minority of contemporary states currently possess them.

This objection points to a genuine concern, but not, I think, an unanswerable one. The defender of the traditional strategy should make three related points in response. The first begins by reemphasizing that the goods of democracy and political community do not pull all (or even most) of the weight in justifying the state system. The global division of moral labor argument with which we began provides a central part of the case, and that argument concerns the provision of basic welfare goods to the world as a whole. The idea is that the basic welfare of more people, the world over, is better promoted 
within a system of relatively autonomous political communities than it would be on an alternative system. In this sense, the assumed contrast between the welfare of those who benefit from the state system and the welfare of the global poor is a false one. Many more people would arguably be the global poor in the absence of the state system. The state system itself constitutes a device for reducing global poverty: the problem is that it has done so well at this, compared to its predecessors, that we are inclined to take its achievements on that front for granted.

Of course, to suggest that the state system is (now), in its essentials, the best device in terms of global political organization for reducing global poverty is not to say that every aspect of its current incarnation is optimally attuned to that task. Institutional reforms of the kind mentioned earlier are plausibly required, and - this is the second point importantly, moral reforms also. The global division of moral labor argument implies that co-citizen favoritism is morally required, but it does not say to what degree. And it is very likely under current circumstances that the citizens of affluent countries in particular permit each other too much. ${ }^{30}$ We can do a lot more for global poverty while retaining a moral code that allows for special duties between compatriots.

What of the more difficult case concerning the 'rarefied' welfare goods of democracy and political community and, possibly, domestic distributive fairness? Can the special duties of distributive justice that I have suggested are necessary to sustain those goods stand up against the utilitarian imperative to alleviate the sufferings of the very poor? To begin with, if the welfare benefits of democracy and political community are as significant as I earlier suggested they are, their characterization as 'rarefied' is not obviously apt. The real challenge, then, seems to be the small proportion of the world's population currently able to benefit from those goods. It seems that what we need to respond adequately to the challenge at issue is to supplement the earlier more 'local' utilitarian justification for democracy and political community with

${ }^{30}$ Goodin's paper ends with the claim that 'in the present world system it is often perhaps ordinarily - wrong to give priority to the claims of our compatriots', given that the global division of moral labor has in fact been poorly effected and special responsibilities have been assigned to some states that are either unable or unwilling to discharge them effectively (Goodin, 'What Is So Special', p. 686). This conclusion, as stated (particularly the 'ordinarily' claim), seems to me to be overly strong. Some degree of ongoing cocitizen favoritism is required to maintain the basic functioning of the state system. If we accept my argument that the state system, suitably reformed, is the best way of implementing the global division of moral labor under current conditions, and unless we mean to rescind Goodin's earlier arguments about the welfarist importance of that general device, we will want to continue our practice of 'ordinarily' giving priority to the claims of our compatriots. What we will want to change is the extent and content of that priority. 
an explicitly universalistic justification that shows why the attainment of fully flourishing democratic communities is of benefit to those who live outside as well as within the states that secure them.

We can point to two such general benefits. First, the existence of healthy democratic states serves to promote the extension of democracy to other parts of the world. Existing democratic states can serve as a source of inspiration for those living in other states; ${ }^{31}$ they are also able, in more ambitious guise, to provide active assistance to those working to establish liberal rights in their own states. Second, democratic states have historically been more likely than non-democratic states to promote a number of valuable causes and outcomes other than democracy itself, including the global environmental movement, the development of the global economy, the expansion of international law, the initiation of international peacekeeping operations and global measures for the protection of human rights. Such achievements as have been made in these and allied areas are admittedly fragile and incomplete, but, to the extent that they have succeeded, they have led to genuine improvements in global welfare, including the welfare of the global poor. When we consider the issue from this perspective, it would seem very short-sighted to argue for a redirection of national priorities entirely away from the sustaining of democratic community, in favor of an exclusive direct attention to the needs of the world's poor. The third and final response that the defender of the traditional strategy should give, then, is to emphasize the need for a longer-term, strategic vision of what the promotion of global welfare - including the alleviation of global poverty - will require.

\section{SPECIAL, BUT NOT THAT SPECIAL}

In section III I argued that our utilitarian argument for the state system, if successful, supports, in three different ways, the claim that shared membership in a modern state is a special 'distributive-justicegenerative' relation. But - to return to the broader question with which the article began - just how special? Some arguments for state-specific duties of distributive justice imply that distributive justice is exhausted by such duties. ${ }^{32}$ Nothing in the arguments given above, however,

31 See van Parijs's similar claim that existing liberal states demonstrate 'that a strongly redistributive economy is more than a fancy dream . . . thereby provid[ing] a tangible model ... for redistributive strategies in each country' (Philippe Van Parijs, 'Commentary: Citizenship Exploitation, Unequal Exchange and the Breakdown of Popular Sovereignty', Free Movement: Ethical Issues in the Transnational Migration of People and Money, ed. B. Barry and R. Goodin (University Park, 1992), p. 164).

32 Or, better, they are claimed by their proponents to have that implication. In the more prominent versions of such arguments, we are pointed to a form of associative relation between persons that is said to be the exclusive 'ground' of distributive justice and we are 
generates a conclusion of that kind. Although the global division of moral labor argument and the importance of the state-dependent goods that I have highlighted justify our favoring our co-citizens' interests in certain ways when setting the terms of our country's basic political and economic institutions, this hardly suggests that distributive justice permits us to pay no attention at all to the resource-related interests of those living outside our state. In our world, such a policy would be acceptable, coming from a utilitarian, only if it were not merely administratively more awkward, but in fact impossible for citizens of developed countries to do anything about poverty in developing nations. And that is surely not so. ${ }^{33}$ This suggests that any defensible utilitarian account of distributive justice will incorporate, at a minimum, a set of duties of global distributive justice directed at eliminating the worst forms of human deprivation. ${ }^{34}$

A second reason to think that distributive justice will not be an exclusively intra-state affair for a utilitarian derives from the increasingly dense networks of rule-making and governance that we

then told that the relation in question is, as a matter of fact, confined within the borders of the state. It proves difficult to render the confinement claim plausible. Any associative relation sufficiently abstract in nature to apply to millions of people who have never and will never meet each other is always going to be vulnerable to detection across borders as well as within them, especially given the contemporary density of international political and economic activity. So the same arguments that purport to tell us that the state is entirely special in relation to distributive justice eventually end up telling us that it isn't. Cohen and Sabel ('Extra Rempublicam, Nulla Justitia') identify this problem in Nagel ('The Problem of Global Justice'); Pogge (Realizing Rawls (Ithaca, 1989)) and Charles Beitz (Political Theory and International Relations (Princeton, 1979)) attempt to do the same in the case of Rawls.

33 The recent literature in development economics and political science has evinced considerable skepticism concerning the extent to which poverty in the developing world can be effectively addressed by foreign aid (see, especially, William Easterly, The White Man's Burden (Harmondsworth, 2006)). But, while past efforts have not been spectacularly successful and some have been positively harmful, there is no evidence that either aid interventions taken individually or the aid industry as a whole are by their very nature useless or counter-productive. (For a philosophically sophisticated discussion of this point, see Garrett Cullity, The Moral Demands of Affluence (Oxford, 2004), ch. 3.) Moreover, even if the aid skeptics were right, there are ways other than simple cash or food grants for affluent countries to promote decent living conditions for the global poor. Among the more promising are the sharing of technological expertise; an effective solution to the third world debt problem; reform of developed country trade policy; and increases in labor migration to the developed world.

${ }^{34}$ This suggestion might be disputed on the ground that such poverty-related requirements are best understood as duties of 'humanity' rather than of 'justice'. It is hard to accord this well-worn distinction much significance within utilitarianism. For utilitarians, duties characteristically cast as 'humanitarian' and duties characteristically cast as 'justice-based' will both be secondary principles (if they make the grade), and there seems to be no great theoretical gain to be had in treating them as categorically different. I am inclined to think it an advantage of the utilitarian approach that it does not give much weight to the distinction between duties of justice and duties of humanity, which is difficult to draw on a basis that both allows for a crisp categorization of duties and has evident moral significance. 
now see at the international level. Global politics is today shaped and sustained by a huge number of rules (a) on an extensive and diverse range of subjects, (b) made, elaborated, and applied by a network of established global and international institutions, (c) in a process of extensive cross-border cooperation, (d) resulting in relations of dense interdependence between distinct political communities, (e) with significant consequences for the distribution of resources across the world's population, and (f) with consequences that would have been significantly different if other available rules had been applied instead. These features strongly suggest that the same conditions that render principles of distributive fairness apt and utilitarian-friendly in domestic politics, if so they do, will also apply in at least some cases beyond the state.

If what I have argued here is correct, then, utilitarians will be able to strike an attractive balance between the two intuitions with which we started. Their theory will support the idea that membership in a state generates special duties of distributive justice, while also supporting the idea that it is not the only thing to do so. This is an appealing result and one that I think most philosophers writing in this area would like their theories to generate.

The preceding discussion provides a much stronger case for statespecific duties of distributive justice under utilitarianism than has so far been given on the traditional strategy. That case is avowedly conditional. It ultimately depends on: (1) an empirical hypothesis that the modern state system is not rotten to its core, so that reform and supplementation might fix some of its more pressing problems and (2) a claim about our epistemic situation: to the effect that we have insufficient evidence showing that a radically alternative system would do any better in welfare terms than the present one to justify the costs of major revolution. So, as ever, the world and the mind hold the utilitarian hostage. The idea that we do have distributive duties to cocitizens that we do not have to others is not here getting the unequivocal support that it is accorded by some other moral theories and by some interpretations of common-sense morality. For those who think that the plausibility of utilitarianism depends on its ability to accommodate the more persistent elements of the latter, the theory as a whole may to that extent appear deficient. But, of course, the utilitarian always has a way out. For, as writers in the tradition are apt to remind us when common sense rebels, it might be us, rather than the theory, that's at fault. ${ }^{35}$

hdebres@wellesley.edu

${ }^{35}$ Many thanks to Matthew Barrett, Joshua Cohen, Sally Haslanger, and several audiences who heard earlier versions of this article for their helpful comments. 